\title{
THE INFLUENCE OF AUDITOR PROFESSIONALISM AND AUDITOR'S COMPETENCY ON AUDIT QUALITY
}

\author{
Widyanah \\ Langlangbuana University, Indonesia \\ Wiidyaapriil@gmail.com
}

\begin{abstract}
This research was carried out on Nasari Savings and Loans (KSP). The main objective of this research is to find out the influence of professionalism and auditor competence on audit quality on KSP Nasari. The method used in this research is descriptive method and verification method using a quantitative approach. The data used in this study is primary data. Data collection is done by direct observation, interviews, questionnaires and literature which is done by reading and studying books related to the problem. The population used for this study was 40 people, they consisted of Internal Control Unit (SPI) on KSP Nasari. The results of this study are professionalism and auditor competence positively and significantly affect audit quality.
\end{abstract}

Keywords: Auditor Professionalism, Auditor Competence and Audit Quality

\section{INTRODUCTION}

Internal audit is a management control tool or an extension of the management's hand in performing its supervisory function, so it can be said that the existence of the internal audit function is important to assist management in achieving the stated organizational goals. Moreover, current developments have placed the internal audit function in a more important position than before, where there has been a shift in the role of internal audit from a function that is tasked with providing assessment and supervision to a function that can provide operational and strategic input, therefore internal audit is required. to work professionally (Nugraha: 2015). The growing business world in Indonesia makes the existence of internal auditors increasingly needed. However, currently, the internal auditor profession is still relatively small. Based on data from The Institute Internal Auditors (IIA) Indonesia, it has only issued around 473 professional certification auditors.In details, 272 Certified Internal Auditors (CIA), 77 Certification in Risk Management Assurance (CRMA), Certification in
Control Self-Assessment (CCSA)) as many as 56, Certified Government Auditing Professional (CGAP) for 53, and Certified Financial Services Auditor (CFSA) Angela Simatupang, Governor of IIA said that the internal auditor profession currently plays a vital role in a company. "Like the brakes on a car, so we need an internal auditor to stop something if it is no longer in accordance with the changing times. Brakes are only for stopping or reducing the speed of the vehicle but they do not contribute significantly to the direction and goals of the company, "said Angela at the IIA's annual conference at the Westin Nusa Dua, Bali, in her press statement. According to him, internal auditors are also like a navigation system that can provide information to companies about developing conditions. "This profession must be able to provide assurance that the organization is indeed on the right track to achieve its goals," he said. (http://www.kompas.co.id). For this reason, he hopes that the IIA annual conference that is held can raise awareness of the importance of the internal audit function, and also improve the internal audit profession. Hari 
Setianto, President of IIA Indonesia added, this conference is an event for all professionals in Indonesia who are involved in areas related to internal audit, governance, risk management and internal control, regardless of the attributes of certain sectors. According to him, at this conference, participants can share experiences and views on how the internal auditor profession can provide value to the organizations in which they are located. (http://www.kompas.co.id). One of the phenomena of internal auditor professionalism, organizational commitment and performance of internal auditors is the BUMN in Bandung, namely PT Pos Indonesia. The Attorney General's Office (Kejagung) searched and seized a number of Portable Data Terminals (PDT) or information and communication service tools from $\mathrm{PT}$ Pos Indonesia related to PDT corruption in 2013 with a project value of IDR 50 billion at PT Pos Indonesia. The number of equipment confiscated reached 1,650 units. The weak performance of the company's internal auditors has resulted in state losses due to a number of PT Pos Indonesia officials related to the provision of communication and communication services. This tool is a tool used by officers in the field. Initially it was intended to facilitate control over the delivery of goods, because it was equipped with GPS, said Sardjono. However, in reality, continued Sardjono, the tool did not work so it could not be used. It is therefore reasonable to suspect that the procurement was not in accordance with specifications so that the state loss was estimated at Rp 10.5 billion. (http://www.liputan6.com).

Based on the background of the problem above, the author wishes to conduct research "The Effect of Professionalism and Auditor Competence on Audit Quality at KSP Nasari" According to Sukriso (2012: 4) states that, "Audit is an examination that is carried out critically and systematically by an independent party, towards financial statements prepared by management along with accounting records and supporting evidence, with the aim of being able to provide an opinion regarding the fairness of the financial statements ". According to Arens (2009: 48) states that, "Professionalism is a responsibility that is charged more than just fulfilling the responsibilities assigned to it and more than just fulfilling the applicable laws and regulations". From the various definitions above, it can be concluded that professionalism has a meaning related to the profession and requires special intelligence to carry it out. Professionalism refers to the attitude or mentality in the form of a commitment from the members of the profession to always create and improve their professional quality. According to Tuanakotta (2011) explaining the notion of competence, namely, "Competence is the expertise of an auditor obtained from knowledge, experience, and training. Each auditor is required to meet certain requirements to become an auditor. The first general standard (IAI, 2011) states that an audit must be carried out by one or more persons who have sufficient technical expertise and training as an auditor. If an auditor does not have competence in auditing, the level of competence possessed by the auditor is not in accordance with the requirements in the audit standard. From the above definitions, it can be concluded that auditor competence is the knowledge, expertise, experience and skills of an internal auditor that is required to carry out an audit objectively, carefully and thoroughly. According to Budiman (2010) states, "The quality of the resulting audit is assessed by how many auditors provide the correct response for each completed audit work. Audit quality can also be seen from the quality of the decisions taken." 


\section{METHODS}

The method used in this research is descriptive and verification methods using a quantitative approach. The object studied is the influence of auditor professionalism and auditor competence on audit quality at KSP Nasari. The variables in this study include the independent variable Auditor Professionalism (X1), Auditor Competence (X2) and the dependent

\section{RESULT AND DISCCUTION}

The results of the validity test show that the results of all indicators in each statement variable are declared valid. Likewise, the reliability test results show that all research instruments used are statements in the questionnaire that are reliable. Based on the classical assumption test, it is known that the regression model has met the criteria for variable Audit Quality (Y). This study uses primary data, namely data obtained directly from the company using questionnaire answer score data. The population of this research is the employees of SPI at KSP Nasari. The research sample used is non-probability sampling, namely purposive sampling, aimed at the parties who

Competent with the object of this research.

the classical assumption. Furthermore, multiple linear regression analysis was performed to determine the effect of auditor professionalism and auditor competence on audit quality. The results of multiple linear regression analysis of the auditor professionalism variable and based on table 1 above, the regression equation values are obtained as follows:

Table. Multiple Linear Regression Analysis

\begin{tabular}{|c|c|c|c|c|c|c|c|}
\hline \multirow{2}{*}{\multicolumn{2}{|c|}{ Model }} & \multicolumn{2}{|c|}{$\begin{array}{l}\text { Unstandardized } \\
\text { Coefficients }\end{array}$} & $\begin{array}{l}\text { Standardiz } \\
\text { ed } \\
\text { Coefficient } \\
\mathrm{s}\end{array}$ & \multirow[b]{2}{*}{$\mathrm{T}$} & \multirow[b]{2}{*}{ Sig. } & \\
\hline & & B & Std. Error & Beta & & & \\
\hline 1 & (Constant) & 1.945 & 4.715 & & .405 & & .695 \\
\hline & $\begin{array}{l}\text { Auditor } \\
\text { Professionalism }\end{array}$ & .870 & .171 & .710 & 4.841 & & .000 \\
\hline & $\begin{array}{l}\text { Auditor } \\
\text { Competence }\end{array}$ & .365 & .145 & .335 & 2.584 & & .021 \\
\hline
\end{tabular}

a. Dependent Variable: Audit Quality

$Y=1,945+0,870 \times 1+0,365 \times 2$ Where :

X1: Auditor Professionalism

$\mathrm{X}$ : Auditor Competence

Y: Quality Audit Can be interpreted:

The regression coefficient of the auditor professionalism variable $(\mathrm{X} 1)$ is 0.870 , which states that every $1 \%$ increase in the value of professionalism, the audit quality value increases by 0.870 , and the auditor's competence (X2) is 0.365 which states that every $1 \%$ increase in the auditor's competency value, then the audit quality value is 0.365 .

\section{Effect of Auditor Professionalism on Audit Quality}

Hypothesis test of the effect of $\mathrm{X} 1$ on $\mathrm{Y}$ obtained tcount $>$ ttable $(4,841>2,026)$, then $\mathrm{H}_{0}$ is rejected, meaning that there is a significant and significant influence 
between the variables of professionalism on audit quality. After the test is done, the calculation results for each hypothesis (tcount) are compared with ttable. For a $5 \%$ error, the two-tailed test and dk-nk $=40-2-1=37$, then we get $t t_{a b l e}=2.026$ with the following conditions: If $t=$ table $t^{1 / 2} X \leq$ $\mathrm{t} \leq 1 / 2 \mathrm{X}$ then $\mathrm{H}_{0}$ is accepted meaning that there is no the influence of auditor professionalism on audit quality. If the table $\mathrm{t}<-\mathrm{t}^{1 / 2} \mathrm{X}$ or $\mathrm{t}>\mathrm{t}^{1 / 2} \mathrm{X}$ then $\mathrm{H}_{0}$ is rejected, meaning that there is an influence between the professionalism of the auditors on the quality of the audit. Based on the table above 4,841>2,026, it turns out that auditor professionalism has an effect on audit quality, as well as a significant value $<0.05$ with a result of 0.000 , which means that partially there is a significant influence between the variables of auditor professionalism on audit quality.

\section{Effect of Auditor Competence on Audit Quality}

To find out the partial hypothesis between $\mathrm{X}_{2}$ and $\mathrm{Y}$, the following hypothesis can be formulated

Ho: $\beta 1=0$, there is no influence between auditor competence on audit quality.

$\mathrm{H} 1: \beta 1 \neq 0$, there is an influence between the competence of auditors on audit quality.

In testing the hypothesis using the t test, the significance level used is $5 \%$. The formula is as follows:

Note:

$$
t=\frac{b}{S E}
$$

$b=$ regression coefficient

$\mathrm{SE}=$ Standard error

$\mathrm{T}=\mathrm{t}$ count which is then consulted with $\mathrm{t}$ table

After the test is done, the calculation results for each hypothesis $t$ count are compared with $t_{\text {table. }}$ For a $5 \%$ error, the two-tailed test and dk-n-k $=30-3=37$, then we get $t$ table $=2.026$ with the following conditions:

if $\mathrm{t}=$ table $\mathrm{t}^{1 / 2} \mathrm{X} \leq \mathrm{t} \leq{ }^{1 / 2} \mathrm{X}$ then $\mathrm{H}_{0}$ is accepted, meaning that there is no influence between the Auditor's Competence on Audit Quality. If the table $t<-t^{1 / 2} X$ or $t>t 1^{1 / 2} X$ then $H_{0}$ is rejected, meaning that there is an influence between the Auditor's Competence on Audit Quality. Based on the results of $2,584>2,026$, it turns out that Auditor Competence has an effect on Audit Quality as well as a significant value $<0.05$ with a result of 0.019 , which means that partially there is an influence between the Auditor Competence variable on Audit Quality.

\section{CONCLUSION}

The end of this thesis is trying to draw conclusions and provide suggestions. Conclusions are drawn on the basis of the overall analysis results. While the suggestions are conveyed in the hope that they can be useful for KSP Nasari related to professionalism, auditor competence and audit quality. The conclusions of the results of the research conducted are as follows: Auditor professionalism has a positive and significant effect on audit quality at KSP Nasari, because from the research results, the higher the professionalism of an auditor, the higher the audit quality produced by the auditor. Auditor competence has a positive and significant effect on audit quality. In conducting audit activities, knowledge and experience are important things that must be possessed by an auditor so that it can produce good audit quality.

\section{REFERENCES}

Arens, Alvin A., Randal J. Elder, dan Beasley Mark S. (2012). Auditing and Assurances Services - An Integrated Approach. Edisi Keduabelas. Prentice Hall.

Arum Ardianingsih, (2018), Audit Laporan Keuangan, Jakarta : Bumi Aksara 
BPKP. (2010). Peraturan Kepala Badan Pengawasan Keuangan dan pembangunanNomor: PER211/K/JF/2010 Tentang Standar Kompetensi Auditor. Jakarta.

De Angelo, L.E. "Auditor Independence, Low Balling, and Disclosure Regulation". Journal of Accounting and Economics 3, 1981.

Ghozali, H. Imam. (2016). Aplikasi Analisis Multivariate dengan Program IBM SPSS 23. Semarang: Badan Penerbit Universitas Diponegoro.

Hery, (2017), Auditing and Asurans, Jakarta : Grasindo

Ikatan Akuntansi Indonesia (IAI). (2011). Standar Profesional Akuntan Publik. Jakarta: Salemba Empat. Indrawati. (2015). Metode Penelitian Manajemen dan Bisnis: Konvergensi Teknologi

Komunikasi dan Informasi. Bandung: Refika Aditama.

Mulyadi. (2010). Auditing. Edisi Keenam. Buku 1. Jakarta: Salemba Empat.

Mulyadi, (2011). Auditing. Edisi Keenam. Jakarta: Salemba Empat.

Noor, Juliansyah. (2014). Metodologi Penelitian, Skripsi, Tesis, Disertasi, dan Karya Ilmiah. Jakarta: Kencana Prenadamedia Group.

Silaen, Sofar. (2018). Metodologo Penelitian Sosial Untuk Penulisan Skripsi dan Tesis. Bogor: IN MEDIA

Sugiyono. (2012). Metode Penelitian Kuantitatif, Kualitatif, dan R\&D. Bandung : Alfabeta

Sugiyono. (2016). Metode Penelitian Kuantitatif, Kualitatif, dan Kombinasi (Mixed Methods). Bandung: Alfabeta

Sugiyono, (2017). Metode Penelitian. Bandung: Alfabeta
Tuannakotta, Theodorus M. (2011). Berpikir Kritis dalam Auditing. Jakarta: Salemba Empat.

Uma Sekaran, (2006), Metodologi Penelitian untuk Bisnis, Edisi 4, Buku 1, Jakarta: Salemba Empat.

Yuandari, Esti \& Rahman, Topan Aditya. (2017). Metodologi Penelitian

dan Statistika. Bogor: IN MEDIA 